\title{
Article \\ Dark of the World, Shine on Us: The Redemption of Blackness in Ryan Coogler's Black Panther
}

\author{
George FaithfuliD \\ School of Liberal Arts \& Education, Dominican University of California, San Rafael, CA 94901, USA; \\ george.faithful@dominican.edu
}

Received: 14 August 2018; Accepted: 7 October 2018; Published: 8 October 2018

\begin{abstract}
Directed by Ryan Coogler, the film Black Panther portrays the heroes of the fictional African kingdom of Wakanda as godlike. They possess otherworldly sophistication by virtue of their blackness, in contrast to longstanding tendencies in mainstream film toward tokenism, stereotyping, and victimhood in depictions of people of African descent. The superhero the Black Panther, a.k.a. King T'Challa, learns to stand in solidarity with the oppressed, even those in whose oppression he has been unwittingly complicit, such as the children of the African diaspora. As a result, the film can function as catalyst for reflection on the part of viewers in terms of how they might perceive more clearly the complexity, variety, and ambiguity represented by blackness, whether others' or their own, and how they, too, might identify with the Other.
\end{abstract}

Keywords: race; gender; film; post-colonialism; science-fiction; blackness; black theology; superheroes; popular culture; Afrofuturism

\section{Introduction}

Art empowers. By contrast, propaganda merely appears to do so, shackling those who embrace it to narrowly prescribed messages. Ambiguity is the key to the potency of many works of art, as they invite viewers and listeners to do their own interpreting along a range of plausible meanings. A work need not be highbrow in order to possess power as art. In fact, popular appeal may significantly enhance a work's potential to expand, deepen, or call into question the perceptions of those who receive it.

Superhero films can be such art. In their social function, they can even play the role of mythology. As shared narratives, they can convey ethical norms and social values. Implicitly, they encourage reflection on who one is and who one ought to be. In some cases, they invite viewers to take action. Depending on the disposition of the viewer, the act of viewing itself can be a transformative experience of the transcendent.

Historian of religions Charles H. Long suggested some of myth's healing potential: "If we take myth as defined by Mircea Eliade-namely, that myth is a true story-then it is the question of a rendering of American religion as a story that does justice to the inner-life meanings and vitalities of those who were made invisible in the old interpretive schema [e.g., people of color], and it should be a true story that can halt the repressive concealment that has characterized so much of American history" (Long 1986, pp. 153-54). Many previously rendered invisible, voiceless, and without readily identifiable ancestors by American culture's dominant storytellers may now find themselves new possibilities. As mediated by a capable artist, blackness itself can be both a means of redemption and what is redeemed, socio-culturally speaking. 


\subsection{Thesis}

In sharp contrast to mainstream cinematic precedent, Ryan Coogler's Black Panther (2018) depicts godlike characters embodying diverse forms of blackness. The conflict arising from that diversity represents a source of potential intra- and inter-personal religious insight for the viewing public.

\subsection{Preliminary Clarifications}

How might one demonstrate "cinematic precedent"? The following analysis assumes that readers are passingly familiar with the norms of Hollywood depictions of race-or, at the very least, that these norms will be evident once attention has been drawn to them in summary form. Those seeking a more comprehensive account should refer to the most recent edition of Donald Bogle's Toms, Coons, Mulattoes, Mammies, E Bucks: An Interpretive History of Blacks in American Films (Bogle 2004).

In what sense is Black Panther "Ryan Coogler's"? Any successful production is a collaborative work of art. The writer-director is not a solitary genius. Significant credit goes to co-writer Joe Robert Cole and to the film's cast and crew. To label the film "Coogler's" is a terminological convenience underscoring the fact that the finished product owes its shape ultimately but not exclusively to the director.

Coogler and Cole build on substantial printed material from Marvel Comics. For a 1966 storyline in Fantastic Four, Stan Lee and Jack Kirby created T'Challa and his kingdom, Wakanda. The central African nation is secretly the world's most wealthy and technologically advanced, due to the abundant presence of the rare mineral vibranium (in McGregor 2016, pp. 5-45). T'Challa subsequently appeared as the eponymous protagonist of several Black Panther series. Moral complexity, social consciousness, and Afro-centrism marked Don McGregor's writing in the mid-1970s, accentuated by Billy Graham's realistic illustrations. McGregor also introduced T'Challa's nemesis, Killmonger (McGregor 2016, pp. 46-59; Knight 2018). Beginning in the late 1990s, Christopher Priest developed a foil for T'Challa in the form of a cowardly white narrator and side-kick, in effect, the author's projection of the typical comic reader (Priest 2016, pp. 1, 357; Priest 2001). In the late 2000s, Reginald Huldin established T'Challa's sister Shuri as a warrior in her own right and subsequently as the new Black Panther (Huldin 2017). Jonathan Maberry further developed the Dora Milaje, Wakanda's female special forces and royal body guard (Maberry 2017). In the early 2010s, David Liss considered how T'Challa, stripped of his wealth, abilities, and crown, might rebuild himself (Liss 2017). In the mid-2010s, Jonathan Hickman depicted T'Challa in exile contemplating mortality, futility, and impermanence, but holding onto hope nonetheless (Hickman 2014, pp. 70-108). With the exception of Priest, prior to 2016 all authors of Black Panther storylines were white, as were perhaps all of the illustrators, with the exception of Graham.

Black Panther stories told by black people for black people (as well as for others) are different kinds of stories. One common tendency in earlier work was to depict $\mathrm{T}^{\prime} \mathrm{Challa}$ as a fish out of water, undertaking exploits in urban America or in outer space, rather than in his homeland among his people. Ta-Nehesi Coates's and Roxane Gay's recent iterations focus on the internal struggles of Wakanda (Coates 2017a; Gay 2017b). Alongside Coates and Gay, Coogler and Cole offer an array of well-developed Wakandan characters, defined by their home and by their sense of community, with the tension between conflict and solidarity that any complex relationship entails.

This builds on longstanding, if less well-known, precedents. For almost two centuries, proponents of Afrofuturism have depicted the power of people of African descent to convey the dignity of their ancestors, even in the midst of adversity, and to transform the future. As with other forms of science-fiction, Afrofuturist stories are often set in utopian, dystopian, or apocalyptic futures, in alternate presents, or, more rarely, in alternate pasts (Yaszek 2015, pp. 58-63). MacArthur "Genius" Grant-winning Octavia Butler represents one recent example. So does Louis Farrakhan with his claim of receiving revelations for the Nation of Islam on a "Mother Wheel" U.F.O. (Finley 2012, pp. 439-47). Set in Burundi, Saul Williams's forthcoming film Neptune Frost demonstrates the global, rather than strictly American, dimension of the phenomenon (Isama 2018). 
In what sense are the characters of the Black Panther film "godlike"? Wakandans possess a superiority over most of humanity that is relative rather than absolute. With the exception of Christlike $T^{\prime}$ Challa, Wakanda's heroes are more like the feuding Orishas of the Yoruba religion than any Western Deity (Pinn 1998, pp. 58-62). This befits the polytheistic universe of Marvel Comics, which separates superheroes from ordinary mortals and includes some actual gods, such as Ororo Munroe, a.k.a. Storm of the X-Men, T'Challa's sometime consort, and his fellow-Avenger Thor.

What is "blackness"? For the purposes of this article, blackness is the quality of being from or having ancestors from Africa. As used here, the inclusive term embraces "African-ness," "African-American-ness," and other forms of belonging to the African diaspora. Diverse in its manifestations, it might better be rendered plural, were "blacknesses" not unwieldy. Characters' blackness informs and is informed by other dimensions of their identities, such as ethnicity (e.g., Wakandan vs. American), socio-economic status, physical appearance, and lived experience.

Unless otherwise indicated, the default race for all characters discussed below is black African and/or African-American. Because they adhere to the rules of the dialect and are readily understandable as such in context, quotations of African-American vernacular English appear without the confirmation "[sic]" when they diverge from other forms of English.

What constitutes "intra- and inter-personal religious insight"? American anthropologist Clifford Geertz defined a religion as a "system of symbols" that shapes people's assumptions, perspectives, and goals, especially in terms of what their understanding of what is "really real" (Geertz 1973, pp. 90, 124). In their ability to inform such systems, a science-fiction film can be a religious text, theater-going a ritual, and the theater itself a site of theophany. Black Panther does not merely convey religious themes. Viewing the film has the potential to represent a religious experience in that it has the power to transform viewers' systems of symbols.

Symbols can perpetuate oppression. They may do so, in part, by reinforcing stereotypes. At the same time, by offering vivid symbols that dispel stereotypes, a film can liberate. The symbolic liberation offered by Black Panther takes the form of a twofold redemption. First, viewers witness the reconciliation between otherworldly, exalted forms of blackness and this-worldly, marginalized forms. Second, by means of that reconciliation, viewers may participate in a partial rehabilitation of blackness in their personal, communal, and public systems of symbols. This is not to suggest that Black Panther is solitary in effecting the rehabilitation of blackness, much less that such redemption is equally necessary or even possible for all viewers. However, that there should be room for such rehabilitation reveals a great deal about the history of film.

\section{Unrepresentative Representations}

Black Panther depicts black characters with their own narratives, trials, flaws, conflicts, and opportunities for growth. Empowered, dignified, and unvictimized-with one notable exception-they situate the film in stark contrast to its cinematic predecessors. The pioneering works of the Lincoln Motion Picture Company and its peers in Black Hollywood in the first part of the 20th century have now been forgotten by most (Bogle 2005, pp. xii-xiv, 21-24, 165-66). Subsequent depictions of African-Americans in film have been more enduring in the public memory, if more prone to reinforce racial stereotypes. Long after James Baldwin observed the phenomenon, black actors have often found themselves forced into simplistic roles far beneath their level of sophistication, at times succeeding, in spite of the parts given to them, to create "indelible moments, [ ... ] hints of reality, smuggled like contraband into a maudlin tale" (Baldwin 1976, p. 100).

Blaxploitation films of the 1970s offered satire of stereotypes that was often indistinguishable from glorification of them. Viewers found African-Americans trapped in the ghetto, beset by violence, driven by vengeance, and overwhelmed by sexual urges (Lawrence 2008, pp. 94-98). Recent predominantly black productions have tended to follow that precedent.

Indicative of low expectations, When We Were Kings (1996) chronicled the 1974 boxing match between then-reigning world heavyweight champion George Foreman and Muhammad Ali. Held 
in Zaire under its ruthless dictator Mobutu Sese Seko, the event was promoted as "The Rumble in the Jungle" (McCarthy 1996). The documentary's title makes little sense as anything other than an attempted affirmation of what might have constituted the closest thing to royalty Africans and African-Americans had recently achieved, according to one white director.

Even ostensibly positive depictions of black people in mainstream film have tended to be given to tokenism and caricature. The "magical negro" has long been a mainstay of cinematic storytelling. Such characters are plot devices rather than fully developed characters, with the purpose of furthering the journey of a white protagonist by means of otherworldly insight. For example: Will Smith as the title character in The Legend of Bagger Vance (2000), Michael Clarke Duncan as John Coffey in The Green Mile (1999), and Gloria Foster as the Oracle—and to a lesser extent Lawrence Fishburne as Morpheus—in The Matrix (1999). Morgan Freeman as God in Bruce Almighty (2003) and Evan Almighty (2007) simply takes the trope to the ultimate extreme (Ikard 2017, pp. 94-102).

Some recent films have overcome these limitations, succeeding in realistically depicting the dignity of African-Americans in the midst of oppression. However, such "struggle narratives," as Roxane Gay labels them, reinforce the simplistic assumption that the African-American experience-ever spoken of in the grammatical singular-is fundamentally one of victimhood (Gay 2017a, p. 274). The Help (2011) made servitude look charming. The marchers of Selma (2014) left children and grandchildren an America in which King's dream can seem hopelessly naive. The protagonists of Hidden Figures (2016) remained hidden (Satchel 2017, pp. 2-3).

\subsection{Black Women}

The general limitations applied to black characters in mainstream film take on particular constraints in terms of gender. Film historian Lisa Anderson has noted that, until relatively recently, depictions of black women have tended to fall into a limited range of character tropes: "the mammy," gladly caring for everyone but herself; "the tragic mulatta," torn between her black and white parentage; and "the jezebel," consumed by sexual aggression (Anderson 1997, pp. 9, 45, 85-88). For this reason, many have hailed Tyler Perry's "existential superwomen," as sociologist Shayne Lee dubs them, as signs of forward progress (Lee 2015, p. 75). Others lament their underdeveloped nature. Feminist culture critic Tamura Lomax decries Perry's "bitch/saint dichotomy" as "a form of cultural malpractice," due to its tacit assumption that heterosexual Christian marriage should be the goal for all African-American women (Lomax 2014, pp. 125, 142).

Introduced as "two Grace Jones-looking chicks," the first female Wakandan characters viewers of Black Panther meet are members of the Dora Milaje. Beyond her modeling and music career, which established her as a late 20th-century American pop culture icon, Jones portrayed a handful of wild, treacherous, and foreign characters in such films as Conan the Destroyer (1984) and the James Bond film A View to a Kill (1985) (Bogle 2004, p. 291). Whatever their outward resemblance toward Jones, Black Panther's female characters are calm, honorable, and integral to the function of their society.

\subsection{Black Men}

Hollywood's normative depictions of black men have been similarly lacking. They have often appeared as vicious villains (e.g., 1973; Demolition Man 1993; Daredevil 2003). The few previous black male superheroes in film have tended to be neither fully human nor unambiguously good. For example, the half-human, half-vampire Daywalker of Blade (1998) and its sequels (Blade II 2002; Blade Trinity 2004) functions as an iteration of the neither/nor "tragic mulatto" trope, as noted by media studies scholar Robin Means Coleman. The protagonist of Spawn (1997) is similarly problematic. Though black, he was no longer a living human but a damned soul back from hell (Means Coleman 2013, pp. 193-94). Whether as antagonists or as semi-malevolent protagonists, many portrayals have reinforced the stereotype of black male hypermasculinity (Wanzo 2015, pp. 317-18). Perhaps because of that quality, in addition to their expendability in many narratives, black male characters seem disproportionately predisposed to being early victims in action, horror, and science-fiction films, as in Enter the Dragon 
(1973), Star Trek II: The Wrath of Khan (1982), Aliens (1986), and Heat (1995). In those same genres, few popular films have portrayed male heroes of any race as possessing significant emotional vulnerability. The black man as harmless buffoon is another common character trope, even in predominantly black productions featuring a protagonist who is a king, as in Coming to America (1988), or a superhero, as in Blank Man (1994) (Carrington 2015, p. 177).

The persona of T'Challa (Chadwick Boseman) represents a radical break from those stereotypes. Bold in battle, measured in his words, and cautious in his foreign policy yet prone to take significant personal risks in covert action, $\mathrm{T}^{\prime} \mathrm{Challa}$ is a complex leader. Tongue-tied around his beloved, he often fails to recognize when he needs help and places a naïvely unwavering trust in his father. These qualities make him imperfect, but in the manner of a well-developed character. Even barring the radical transformation he does, in fact, undergo, $\mathrm{T}^{\prime} \mathrm{Challa}$ would still have possessed significance as a step toward greater realism in Hollywood's depictions of black men.

\subsection{Black Bodies}

With the complexions of the cast, almost without exception, falling somewhere on the spectrum between burnt caramel and ebony, the people of Wakanda embody a consistently Afrocentric standard of beauty. This is as unsurprising, given Black Panther's premise, as it is unprecedented, given Hollywood's history of casting black actors who adhere to Eurocentric standards. The phenomenon of blackface further accentuates this history. Zoe Saldana in Nina (2016) represents one recent example of both trends (Sun 2016).

Black hair, especially black women's hair, has been hotly contested territory in conflicts between Afro- and Eurocentric standards of beauty, both on screen and off (Coates 2017b, pp. 93-95). Because of this, the natural hair of the characters of Black Panther represents a vivid example of the film's unequivocal legitimation of natural forms of blackness. Whether cropped close, knotted, twisted in short curls, tied in buns, coiled, tightly braided, wrapped in tassels, or pulled up in dreadlocks, the characters' hair is unsullied by any straightening irons or chemical relaxers (Williams 2018; Martin 2018). The sole instance of straightened hair in the film is Okoye's wig, which she disparages, wearing it as part of her disguise until she finds better use for it as a weapon.

Black Panther also celebrates some forms of body modification. Like those of the rest of the Dora Milaje, the tattoos on Okoye's clean-shaven scalp accentuate the uncompromising permanence of her commitment. Whether paired with a traditional tribal robe or a business suit, the lip plate worn by the elder of the River Tribe serves to underline his dignified status. Contrast this with the dehumanizing old circus poster: “Ringling Bros and Barnum \& Bailey present: new to civilization from Africa's darkest depths, tribe of genuine Ubangi savages" - not the name of an actual tribe, as cultural historian Janet Davis explains- "with mouths and [plated] lips as large as those of full grown crocodiles" (Davis 2002, p. 134).

In terms of body type, Black Panther adheres to a narrow range, apart from the Wakandan elders and priests. Diversity of physique is even more lacking among the female cast, underscoring one of the film's most significant flaws. Equitable representation of gender in mainstream film remains elusive.

\section{Children of No Lesser Goddess}

Of the African-American "identity crisis," pioneering black liberation theologian James Cone wrote:

You have to be black, with a knowledge of the history of this country, to know what America means to black persons. You also have to know what it means to be a nonperson, a nothing, a person with no past, to know what black power is all about. Survival as a person means not only food and shelter, but also belonging to a community that remembers and understands the meaning of its past. Black consciousness is an attempt to recover a past deliberately destroyed by slave masters, an attempt to revive old survival symbols and create new ones. (Cone 2003, p. 12) 
Wakanda represents such a symbol, standing in as a specific homeland for African-Americans who know of their distant ancestors only that they came from somewhere vague in Africa. Wakanda further serves as a reminder that, prior to European colonial invasion, civilizations flourished in Africa. Nigerian-American historian Saheed Aderinto counts ninety-one of them (Aderinto 2017, pp. ix-xi). Wakanda is an unmistakable place of pride for all who identify with it, unlike the assumed-to-be impoverished, uneducated, and helpless generic "country of Africa" of much public discourse (Adichie 2009; John 2013).

For those familiar with images of savage cannibals on "the dark continent" and in "darkest Africa," such as those of Hollywood's so-called golden age, the Golden City and its enlightened people shine all the brighter. As a mark of Wakanda's distinctness and of the production's commitment to authenticity, the South African Xhosa language serves as the spoken language of Wakanda, paired with an original alphabet and script (Harris 2018; Desowitz 2018). A Xhosan accent also marks Wakandan characters' lines in English, a departure from the "generic African accent" on which mainstream productions have typically relied (Quartz 2015).

As a token of the complexity of the film's Wakandan characters, they fundamentally disagree about what Wakanda is. When it faces radical change, what is the nation's core essence that must be protected at all costs? The rule of Wakandan law? The nation's traditions? The people who officially, until recently, represented what the nation was? The dilemma remains unanswered in the film, resolved by a miracle that obviates a choice between these distinct options.

\subsection{The Mother Goddess}

The panther goddess Bast is a subtle presence throughout the film. Derived from Bastet, the feline goddess of ancient Egypt, she combines the fierceness of a lion with the aloof, unpredictable, and more approachable nature of a cat (De Jong 2002, p. 123). The opening narrator recounts how Bast guided a warrior-shaman to partake of the Heart-Shaped Herb, endowed with vibranium-derived powers, enabling him to become the first Black Panther (Trumbore 2018). Apart from this, she receives mention in a declaration of anticipated victory in her name, a prayer for healing by her power, and a curse ("by Bast!"). Visible signs extend a sense of her presence. Panthers prowl alongside former kings in the Ancestral Plane. Panther iconography marks T'Challa's gear, Shuri's hand blasters, and the mouth of a mountaintop cave overlooking Wakanda.

As metaphorical daughters of the goddess, the well-developed female characters of Black Panther illustrate the multi-faceted nature of Wakandans' godlikeness. Okoye, Nakia, Shuri, Ramonda, and the Dora Milaje comprise the majority of on-screen heroes, especially once battle lines are drawn between the supporters of $\mathrm{T}^{\prime}$ Challa and those of Killmonger. They help $\mathrm{T}^{\prime}$ Challa survive. Their relationships with him save his character from the tired hypermasculinity to which so many male superheroes and black characters have fallen victim, both on screen and in print.

Whatever their strengths, these same female characters are significantly if not exclusively defined by their relationships to male characters in roles such as caretaker, lover, sister, and mother. $\mathrm{T}^{\prime} \mathrm{Challa}$ 's journey as hero serves as the film's focus. If Black Panther represents a step toward the expansion of gender roles in its relevant sub-genres, it is a significant but slight one. One manifestation of this: the relegation of Ayo (Florence Kasumba), the second in command of the Dora Milaje, to a minor role and the omission of her romantic relationship with a fellow female officer, well-established in the comics but absent from the film (Broadnax and Riesman 2018).

\subsection{The Warrior}

Esteemed as Wakanda's greatest warrior, General Okoye (Danai Gurira) of the Dora Milaje prevails against her enemies in combat because of her superior situational awareness, reflexes, and expertise, rather than because of brute strength. Crouched atop of a moving car, she stops a fleeing vehicle with a single spear throw. Okoye's physical prowess is an expression of her mental precision. 
Hers, too, is a generous spirit. Upon helping T'Challa liberate a group of female captives, she insists that one of their captors be liberated. She readily recognizes that he himself is a victim, conscripted as a child soldier before becoming a perpetrator of further violence.

Okoye possesses an uncompromising loyalty to Wakanda. She does not hesitate to back Killmonger's claim to the throne when the usurper seems to defeat $\mathrm{T}^{\prime}$ Challa in trial-by-combat. Neither does she hesitate to risk her life to support T'Challa again once he returns. When $W^{\prime}$ Kabi (Daniel Kaluuya), her beloved and a continuing Killmonger supporter, meets her in combat, he asks if she would take his life. "For Wakanda?" she replies. "Without question."

\subsection{The Spy}

As one of Wakanda's foremost spies, Nakia (Lupita Nyong'o) navigates others' languages and cultures as if they were her own. From the world's foremost nation, she makes herself a captive among the victims of human trafficking, becoming indistinguishable from them. She speaks fluent Korean with a fish vendor and gatekeeper for an underground casino.

Beneath Nakia's malleable public selves lies inner certitude. She shrewdly saves the last of the Heart-Shaped Herb, even as Killmonger has the rest destroyed, enabling $\mathrm{T}^{\prime} \mathrm{Challa}$ to regain his powers. When he beseeches her to take a place beside him on the throne, she reminds him how much more important is her work on behalf of the marginalized. T'Challa chides her, "If you were not so stubborn, you would make a great queen." She replies, "I would make a great queen because I am so stubborn!"

\subsection{The Genius}

Although centuries of scientific research laid a foundation, Wakanda must give credit to Shuri (Letitia Wright) for its latest breakthroughs. She developed a high-speed train system. From the comfort of her lab, she can drive a car located thousands of miles away. She continues to improve already-cutting-edge technologies, designing a new Black Panther suit able to absorb kinetic energy. The other advanced weapons of the nation owe their latest iterations to her engineering.

Technical expertise is her specialty, but she shares a spirit of self-sacrifice with her Wakandan sisters. She shoulders the burden of caring for a white fugitive in their midst. When she flees Killmonger, she smuggles out a spare Black Panther suit, making it possible for a newly revived $\mathrm{T}^{\prime}$ Challa to defeat his foe. Although not ordinarily tasked with serving on the front lines, when duty calls, Shuri does not hesitate to risk her life.

\subsection{The Conscience of a Nation}

Queen Ramonda (Angela Basset) grounds Wakanda in a sense of enduring community bound by tradition, honor, and family. Step-mother to T'Challa and Shuri, she adores them as her own children. ${ }^{1}$ Staid in her demeanor, at times officious or stern, the Queen Mother demonstrates fierceness when the need arises. As a final test prior to coronation, Prince T'Challa faces M'Baku (Winston Duke) of the Jabari tribe in trial-by-combat at the ceremonial waterfalls. Bloodied, limp, and bleary-eyed, $\mathrm{T}^{\prime} \mathrm{Challa}$ seems defeated until Ramonda screams, "Show him who you are!"

The widow of the recently deceased T'Chaka takes her place in the Tribal Council beside the new king, making her voice heard in pursuit of truth, justice, and righteousness. She decries Killmonger as a charlatan. When he provides proof of his royal identity, she demands to hear from her son what he might know of the ugly truth. His father, her husband, killed his own brother and abandoned his orphaned nephew. That he covered up these actions represents a betrayal of her trust not least of all.

Ramonda is a woman of action. Initially skeptical of the plan, she conspires with Shuri and Nakia to enlist M'Baku's help, even if it means giving him the last of the Heart-Shaped Herb. A person of honor himself, M'Baku responds by leading them to T'Challa's comatose body. Ramonda crushes the

1 Her status as T'Chaka's second wife is well-established in the comics and seems assumed in the film (Coates 2016). 
Herb, pours it over T'Challa's lips, and pleads with their ancestors and with Bast to bring him back from the brink of death.

\section{The Enemy, the Other, My Brother}

Wakandans represent otherworldly, godlike forms of blackness. The Golden City and their aircraft- "like a Bugatti spaceship," as one Oakland child comments-accentuate this. At the utmost height of attainable human excellence, they possess one primary flaw. After millennia of holding themselves aloof, they persist in refusing to participate in the affairs of others, even those in dire need. The varieties of their unincarnate blackness are no less radiant. But they need to reckon with the damage wrought by their inaction.

Killmonger (Michael B. Jordan), the antagonist, bridges the gap between unincarnate, otherworldly forms blackness and oppressed, this-worldly forms. This dynamic is accentuated by Jordan's previous work with Coogler. Blurring the line between cinematic drama and documentary, Fruitvale Station (2013) chronicles the last day in the life of Oakland-resident Oscar Grant III, played by Jordan. While Grant was riding a commuter train with his girlfriend and a group of friends, an old enemy from prison picked a fight with him. Police responded, forced Grant to the ground, and restrained him. Despite Grant's protests that he was unable to obey a command because an officer's knee was on his neck, a rookie panicked and shot him in the back. The film leaves unanswered the questions why such things occur and how one should live in the aftermath. Billed as a sixth Rocky sequel, Creed (2015) features Jordan as Adonis "Hollywood Donnie" Johnson, the illegitimate son of former boxing world heavyweight champion Apollo Creed. Even after taking on his father's last name, he is driven to violence, both in and outside of the ring, by the desire to "prove [ . . ] that I'm not a mistake," as he confides to his mentor. Unlike Grant and Creed, Killmonger is in a position to seek definitive answers.

Black Panther opens on a blank screen with the sound of a boy asking for his father in Xhosa: "Baba?" The father replies, "Yes, my son?" Viewers later learn that the father is Prince N'Jobou (Sterling K. Brown), on an undercover Wakandan War Dog assignment in Oakland, California, speaking to a young N'Jadaka, later known as Killmonger. "Tell me a story," the boy pleads. His father chuckles and replies, "Which one?" The boy answers, "The story of home." The boy has doubtless heard and requested this story many times before. This narration provides viewers their first introduction to Wakanda, how the nation began, and why its strength became a secret. The boy asks, "And we still hide, Baba?" His baba replies, "Yes." The boy asks, "Why?" His father answers with action rather than words.

The year, 1992, coincides with the riots in Los Angeles following the exoneration of white police officers caught on camera beating black motorist Rodney King. As a black boy identifying both as African-American and as Wakandan, N'Jadaka asks his father why Wakanda did nothing to help victims of such manifest injustice. Working to incite a black uprising, his father collaborates with white South African arms dealer Ulysses Klaue (Andy Serkis) to smuggle vibranium out of Wakanda. Prince N'Jobou pays for this treason with his life. Whether King T'Chaka killing his brother represents murder, lawful execution, or justifiable action in defense of his informer Zuri is open to debate. Zuri, who becomes High Priest, later tells $\mathrm{T}^{\prime}$ Challa that their rationale for leaving the child who would become Killmonger was that "we had to maintain the lie" of Wakanda's powerlessness.

\subsection{Behind the Masks}

If Wakanda would not unveil itself, Killmonger would do so, wearing many masks in order to reach his goal. He graduated from the U.S. Naval Academy at nineteen, pursued graduate studies at the Massachusetts Institute of Technology, and served as a Navy SEAL before becoming part of Joint Special Operations Command "ghost units" tasked with producing regime change. White C.I.A. agent Everett K. Ross (Martin Freeman) explains this, dismissing Killmonger's plan of imposing Wakandan 
imperial rule worldwide as merely an expression of his training. Rather, Killmonger's course of action is an authentic if hypocritical response to his experience of oppression.

Ross also neglects to mention his agency's history of undermining national sovereignty abroad. In the second half of the 20th century, the C.I.A. launched a failed invasion of Cuba; conducted a secret war in Laos; sponsored insurgencies in Tibet, North Vietnam, Angola, Afghanistan, and Nicaragua; coordinated successful coups in Iran and Guatemala; and planned subsequent failed ones in Haiti, Chile, Syria (twice), Indonesia (twice), and Ethiopia. Prior to the Carter Administration, the C.I.A. contributed to the white South African government's efforts to remain in power at the expense of black South Africans because it opposed the Soviet Union, even locating anti-apartheid leader Nelson Mandela on its behalf, leading to his arrest and subsequent twenty-seven years of imprisonment (Weiner 2007; Kwazulu-Natal 2013).

Trained by the U.S. government, the half-Wakandan orphan became a prodigy of death worthy of his nickname. But that is not who viewers first meet on screen. The bespectacled visitor at the fictitious Museum of Great Britain peppers the white in-house expert in African artifacts with questions. Despite his ostensible harmlessness, no fewer than four white security guards flank him as she offers answers. He corrects her about the origins of an axe. She scoffs. When she protests his plan to take it, he asks, "How do you think your ancestors got these? You think they paid a fair price? Or did they take it, like they took everything else?" As part of the score, Killmonger claims a mask. Some have recognized its style as similar to that of the Igbo, making it a potent reminder of that tribe's history of victimization by the transatlantic slave trade (Baldera 2018). ${ }^{2}$ Killmonger unmasks the fraud of white imperialism, which expanded its power by means of theft, murder, rape, and slavery in the name of "civilization."

Klaue represents the worst contemporary iterations of this. The middle-aged white South African, with a thick Afrikaans accent, grew up enjoying the worldly advantages apartheid offered to people like him. He acquires raw materials for weapons which he sells "to the highest bidder," in his words. He hires mercenaries, such as Killmonger, as part of his crew in order to take life whenever suits his professional goals. Both actively and passively, he is complicit in the violent exploitation of others.

Wearing his Igbo-style mask, Killmonger seems to rescue his employer. However, Klaue is worth more to him dead than alive. It does not matter to Killmonger that his unnamed girlfriend dies in the process. On the edge of Wakanda, Killmonger drops Klaue's corpse at the feet of W'Kabi, the leader of the Border Tribe's forces in Wakanda's army. As the son of one of Klaue's victims and as a previous advocate for Wakandan military adventurism, W'Kabi is a ready ally for Killmonger.

Killmonger holds up a mirror before an unmasked Wakanda for its elders to behold what their nation truly is. Killmonger reveals his own identity, flashing the royal ring and War Dog tattoo to prove it, thus situating himself in Wakanda's story as both one of its children and one of its victims. Because of the inaction of the nation's leaders, blood is on their hands. Billions of people of color in the world live under significant social, economic, and environmental oppression. Instead of liberating them, Wakandans have chosen the comfort of isolation.

Laying claim to Wakanda's throne and to the title of Black Panther, Killmonger challenges T'Challa to trial-by-combat. Cousin faces cousin, the son of a killer against the son of his victim and brother. $\mathrm{T}^{\prime}$ Challa has an opportunity to best Killmonger but offers him an opportunity to yield. He refuses. True to his name, Killmonger stabs Zuri and throws T'Challa from the falls. The Wakandan world now on its head, an inverted shot of the throne room slowly rights itself to reveal King N'Jdaka Killmonger. After promising worldwide violence, he proudly proclaims, like many before him, that the sun will never set on his empire (Büchmann 1895, p. 157). He identifies the fundamental geopolitical problem as the question of who is in power, rather than as the problem of imbalances of power themselves. Killmonger wants the oppressed to become oppressors, so long as they are black.

2 The mask also bears a striking resemblance to the one drawn by Francis Portela in Black Panther \#37 (in Huldin 2017). 


\subsection{Reorientation}

At the outset, prior to reckoning with Killmonger, $\mathrm{T}^{\prime}$ Challa is an isolationist in the tradition of his forefathers, committed to maintaining the national secret. Knowledge of Killmonger's existence is enough to shatter the sense of righteousness $\mathrm{T}^{\prime} \mathrm{Challa}$ ascribed to his father. $\mathrm{T}^{\prime}$ Challa's confrontation with Killmonger as a person demands new ways of thinking for $\mathrm{T}^{\prime} \mathrm{Challa}$ and, under his leadership, new ways of life for Wakanda.

Ahistorical individualism hinders many from pursuing justice. One must acknowledge that one does not make decisions in a vacuum and that one's actions and failures to act impact others, especially in light of the histories of those involved. One may even possess a burden of responsibility to act because of others' past mistakes.

T'Challa's father, King T'Chaka (John Kani), once seemed to acknowledge all of this. In Captain America: Civil War (2016), which immediately precedes Black Panther, he proclaimed to international news media, "Victory at the expense of the innocent is no victory at all." When vibranium stolen from Wakanda was involved in the death of numerous civilians in Sokovia, an impoverished Eastern European nation, $\mathrm{T}^{\prime}$ Chaka led a United Nations effort to mitigate such tragedies in the future.

In Black Panther it is T'Challa's turn to wrestle with the problematic legacy of others' mistakes. As $\mathrm{T}^{\prime}$ Challa lies dying, the sun already rising on him in the Ancestral Plane, $\mathrm{T}^{\prime} \mathrm{Chaka}$ invites his son into the company of fellow former kings. T'Challa refuses. "Why?" he asks. "Why didn't you bring the boy home? Why, Baba?" What justified Wakanda doing nothing in the face of injustice? Killmonger asked his own baba a version of the same question. T'Challa's father pleads the importance of Wakandan secrecy. T'Challa rejects this. Turning to his other forefathers, he shames them for their cowardice, for the pain they caused others through their neglect, and for the "monster of our own making" that Killmonger has become.

Even among his fellow godlike Wakandans, T'Challa becomes Christlike in his self-emptying and in his identification with all of humanity. He passes from life into death, abandoning his pride, his power, and his crown, only to take them up again when he rises from the dead. Oppressors are oppressors, even if they themselves were once oppressed. "You have become them," T'Challa warns Killmonger in their final duel. Killmonger shrugs this off with more threats of violence against all who might stand in his path and against their descendants, as well.

In a speech at the United Nations in Vienna, where his father died, $\mathrm{T}^{\prime}$ Challa declares an end to Wakandan isolationism on the basis of humans' shared connections, without denying their distinctness: "Now, more than ever, the illusions of division threaten our very existence. We all know the truth. More connects us than separates us. But in times of crisis, the wise build bridges while the foolish build barriers. We must find a way to look after one another as if we were one single tribe." One may perceive in this something of the internationalism marking the later stages of the lives of both Martin Luther King, Jr., and Malcolm X (Cone 2012, p. 314). Like both civil rights leaders, T'Challa's identification with humanity is not uniform, but prioritizes the socio-economically and racially oppressed, such as those living in the neighborhood in Oakland where his cousin was raised and where his uncle died.

On the site of the now-condemned building where that death occurred $\mathrm{T}^{\prime}$ Challa plans to build the first Wakandan International Outreach Center. The hero attempts to make the world a better place by investing in the ghetto and not simply by vanquishing foes. For an action/adventure blockbuster, such a display of humanitarian largesse verges on unprecedented sophistication. In realistic terms, it is also a gesture of profound futility. $\mathrm{T}^{\prime}$ Challa seems to be in danger of developing an Afro-centric version of the "white savior complex," in which an outsider lacking first-hand local knowledge but flush with cash arrives hoping to make a difference, but ends up either accomplishing nothing or doing damage, no matter how much better the do-gooder feels about themselves (Cole 2012).

\section{Revelation}

The film itself may be more likely to succeed where its hero falls short. Black Panther does not merely convey a story about redemption. In terms of representing blackness(es), it redeems. By pushing the boundary between the unreality of a superhero narrative and the socio-cultural realities of many 
viewers, Black Panther invites them to rethink the kinds of stories they could tell. These stories include those honoring one's ancestors who may have remained unvanquished in their pride, no matter how desolate their physical or socio-economic condition may have been. The film opens up the possibility for a greater variety of narratives regarding what lived blackness can entail. Through the visual storytelling of film, these insights have the power to shape viewers' understanding of ultimate reality in terms of people, whether others or themselves, including in their blackness.

\subsection{Happily Never After?}

$\mathrm{T}^{\prime}$ Challa carries his mortally wounded cousin to the mouth of a hilltop cave so that they can watch the sunset together. Drawing his final breaths, Killmonger reminisces. "My pop said Wakanda was the most beautiful thing he ever seen. He promised he was going to show it to me one day. You believe that? A kid from Oakland running around believing in fairy tales." In the context of the scene, Killmonger receives vindication for his unlikely dream. The fairytale kingdom of Wakanda is a reality for him.

For viewers, matters stand differently. The credits roll. The lights come up. The theater doors crack open onto a world where Wakanda is not real and where Oakland is in as much trouble as ever, socio-economically speaking. If that were all that mattered, then it would be tragic for any kids from Oakland to believe in the fairytale that Black Panther represents. However, the mere fact that it projects a variety of heroes who resemble the children of Oakland is a minor triumph, particularly in light of the absence of comparable previous representations. As a result, the film functions as a form of redemptive myth-building (Snead 1994, pp. 143-44).

\subsection{Bound But Unbroken}

Prominent not only in African religions, such as that of the Yoruba, but also in those of East Asia, the ancestors are a presence mediating the divine to their descendants, grounding them in a sense of community that transcends time (Pinn 1998, p. 62). The ancestors stand watching, hoping for, and guiding their descendants. In Black Panther, $\mathrm{T}^{\prime}$ Challa's predecessors are ready to advise the ascendant king when he enters the Ancestral Plane. They wait to welcome the newly dead among them. As part of its broader engagement with the ancestors, the film breaks from an exclusively Judeo-Christian understanding of the afterlife. Not that this is without a few plausible biblical parallels, such as dead Abraham being "gathered to his people" and the "cloud of witnesses" who lived by faith, died, and, now unseen, accompany the living (Gen. 25:8; Heb. 12:1, NRSV).

Ancestor-venerating religions are not for the outwardly victorious alone. Like T'Challa, newly crowned Killmonger speaks with his deceased father on the Ancestral Plane. Past memory and present supernatural experience intermingle, as viewers alternately see Killmonger as a man (Jordan) and as a child (Seth Carr). "No tears for me?" his baba asks. "Everybody dies," the child replies. "It's just life around here." Still, Killmonger the man weeps when his father expresses his pride in what they have accomplished together. Killmonger's resolve remains when $\mathrm{T}^{\prime}$ Challa suggests the possibility of healing to him in his final moments. "Why?" he asks. "So you can just lock me up? Nah. Just bury me in the ocean with my ancestors that jumped from the ships. 'Cause they knew death was better than bondage." He identifies with the slaves, including many Igbo, who drowned themselves, remaining unconquered in death (Chambers 2016, pp. 161-62). They left no direct biological descendants, but Killmonger can claim them as symbolic, spiritual ancestors. That same possibility stands for viewers who identify with that history.

\subsection{Varieties of Blackness}

Blackness has roots as an oppressive theological construct in the conceptual origins of race. In order to distinguish themselves from so-called lesser races, European and European-American colonizers labeled themselves "white" and decreed that, as descendants of Noah's accursed son Ham, the "black" peoples of sub-Saharan Africa were destined by God to be slaves. Subsequent white 
biological definitions of race classified black people as intellectually, morally, and culturally inferior (Jennings 2010, pp. 63-64; Johnson 2004, pp. 3-6; Carter 2008, pp. 79-89).

Much progress has already been made, if unevenly, in public discourse, in popular culture, and in theology toward redeeming blackness. However, there has been a tendency to speak of "the black experience" as a singular, monolithic entity. In black theology, blackness has often functioned as an ontological category, essential to the totality of one's being and yet comprehensible only as distinguished from whiteness. The first generation of theologians producing black theology reinforced the unidimensional nature of the definitive black experience by limiting the conversation to heterosexual, cis, male perspectives. By contrast, Victor Anderson, Anthony Pinn, and other proponents of new understandings of blackness argue that blackness is and must be multifaceted, complex, and, ultimately subjective, permitting a virtually innumerable variety of forms (Anderson 1995, pp. 11-12; Pinn 2010, pp. 38-48).

Black Panther offers vivid public representations of what that diversity can look like. It is imperfect in that contribution to contemporary culture. As noted above, the film fails to depict diversity in terms of sexuality and body type, and its female characters occupy circumscribed roles. Nonetheless, Black Panther challenges the prevailing norms of shallow representations of blackness by depicting black people as unique, multifaceted, and even ambiguous in their blackness, rather than as part of a monolithic community.

People are more likely to change their minds because of lived experience than because of abstract rational argumentation, as Ghanaian-British-American philosopher Kwame Appiah has noted (Appiah 2006, p. 72). By offering such an experience to viewers, Black Panther can function as a tool deconstructing both stereotype-driven racism and colorblindness, in which race is irrelevant, thereby promoting philosophical and theological anthropologies accommodating the understandings people of color already have of themselves.

The language of film makes this possible. Images paired with words in a narrative context can exert power where written language falls short. The reference to Killmonger as a "black operative" serves as a reminder of the morally color-coded defaults of English, in which "white/light = good" as opposed to "black/dark = bad." Even to the point of being excusable, "white lies" are better than regular lies. To have a "soul as black as night" is synonymous with being wholly evil. Such dichotomous thinking is neither realistic nor entertaining for viewers weary of simplistic stories. Coogler does not merely tell his viewers about the godlike possibilities of blackness; he reveals to the receptive among them how they, too, might learn to perceive them, just as $T^{\prime}$ Challa learns to identify with the children of Oakland and many of them, no doubt, learn to identify with him and with other Wakandans.

\section{Conclusions}

"The Black Artist's role in America is to aid in the destruction of America as he knows it," proclaimed poet Amiri Baraka, then known as LeRoi Jones, in 1965. As a means toward that end, he proposed that the Black Artist embrace brutal realism, "to report and reflect so precisely the nature of the society, and of himself in that society, that other men will be moved by the exactness of his rendering" (Jones 1966, p. 251). However, creative destruction is not the only possible role.

In order to build a better world, rather than merely tearing down the problematic present one, Ryan Coogler turns to the tools of science-fiction. By virtue of departing from strict adherence to realism, the genre permits world-building, social experimentation, and limitless resources appropriated to the erstwhile powerless. As a result, its potential for redemptive myth-building is similarly limitless.

Without the right audience, the heroes of Wakanda would not be godlike, much like the Orishas of the Yoruba religion, of whom one proverb says, "if humanity were not, the gods would not be" (Prothero 2010, p. 208). It may be difficult for many white moviegoers to imagine, unprompted, cinematic universes without any heroes who look like them, much less a lifetime of moviegoing with scant realistic portrayals of people with whom they might readily identify. However, given the socio-political and cultural contexts of many viewers, along with their potential histories of viewing 
representations of people of color, Wakandans stand out in godlike glory. In their diversity, in their conflict, and in their self-sacrifice, they embody forms of blackness that have been redeemed from simplistic stereotypes and that might redeem viewers from limited perspectives.

Funding: This research received no external funding.

Acknowledgments: This work would not have been possible without Kenneth Fish, Ethan Annis, Michael Pujals, and A.J. Real of the Dominican University of California; Stephanie Miller of San Francisco Theological Seminary; Jeffrey Jackson of the Graduate Theological Union; Jenna Jackson of the University of California, Berkeley; Crystal Alberts of the University of North Dakota; Cyrano Evans of St. Louis, Missouri; Stuart and Stephanie Hipp of Winston-Salem, North Carolina; and George Faithful, Sr., of Columbus, Ohio.

Conflicts of Interest: The author declares no conflict of interest.

\section{References}

A View to a Kill. 1985. Directed by John Glen. Santa Monica: MGM.

Aderinto, Saheed. 2017. African Kingdoms: An Encyclopedia of Empires and Civilizations. Santa Barbara: ABC-CLIO. Adichie, Chimamanda Ngozi. 2009. The Danger of a Single Story. TED Global. July. Available online: https: / / www.ted.com/talks/chimamanda_adichie_the_danger_of_a_single_story (accessed on 6 August 2018).

Aliens. 1986. Directed by James Cameron. Beverly Hills: Twentieth Century Fox.

Anderson, Victor. 1995. Beyond Ontological Blackness: An Essay on African American Religious and Cultural Criticism. New York: Continuum.

Anderson, Lisa M. 1997. Mammies No More: The Changing Image of Black Women on Stage and Screen. Lanham: Rowman \& Littlefield.

Appiah, Kwame Anthony. 2006. Cosmopolitanism: Ethics in a World of Strangers. New York: W. W. Norton.

Baldera, Josh. 2018. Tragic History of Erik Killmonger's Mask. Hybrid Network. March 5. Available online: http:// www.hybridnetworkyt.com/tragic-history-erik-killmongers-mask/ (accessed on 1 August 2018).

Baldwin, James. 1976. The Devil Finds Work: An Essay. New York: Dial.

Black Panther. 2018. Directed by Ryan Coogler. Burbank: Marvel.

Blade. 1998. Directed by Stephen Norrington. Burbank: Warner Brothers.

Blade II. 2002. Directed by Guillermo del Toro. Burbank: Warner Brothers.

Blade Trinity. 2004. Directed by David S. Goyer. Los Angeles: New Line Cinemas.

Blank Man. 1994. Directed by Mike Binder. Burbank: Columbia Tristar.

Bogle, Donald. 2004. Toms, Coons, Mulattoes, Mammies, \& Bucks: An Interpretive History of Blacks in American Films, 4th ed. New York: Continuum.

Bogle, Donald. 2005. Bright Boulevards, Bold Dreams: The Story of Black Hollywood. New York: One World.

Broadnax, Jamie, and Abraham Riesman. 2018. "Black Panther" Actor Florence Kasuma Addresses the Movie's Lack of Queer Representation. Vulture. February 16. Available online: http:/ /www.vulture.com/2018/02/ black-panther-actor-addresses-lack-of-queer-representation.html (accessed on 2 August 2018).

Bruce Almighty. 2003. Directed by Tom Shadyac. Universal City: Universal Pictures.

Büchmann, Georg. 1895. Geflügelte Worte. Berlin: Haude und Spener.

Captain America: Civil War. 2016. Directed by Anthony Russo and Joe Russo. Burbank: Marvel.

Carrington, Andre. 2015. Drawn into Dialogue: Comic Book Culture and the Scene of Controversy in Milestone Media's Icon. In The Blacker the Ink: Constructions of Black Identity in Comics \& Sequential Art. Edited by Frances Gateward and John Jennings. New Brunswick: Rutgers University Press, pp. 153-70.

Carter, J. Kameron. 2008. Race: A Theological Account. Oxford: Oxford University Press.

Chambers, Douglas B. 2016. The Igbo Diaspora in the Era of the Slave Trade. In Igbo in the Atlantic World: African Origins and Diasporic Destinations. Edited by Toyin Falola and Raphael Chijoke Njoku. Bloomington: Indiana University Press, pp. 156-69.

Coates, Ta-Nehisi. 2016. Black Panther: A Nation under Our Feet Book One. New York: Marvel.

Coates, Ta-Nehisi. 2017a. Black Panther: A Nation under Our Feet Book Three. New York: Marvel.

Coates, Ta-Nehisi. 2017b. We Were Eight Years in Power: An American Tragedy. New York: One World.

Cole, Teju. 2012. The White-Savior Industrial Complex. The Atlantic. March 21. Available online: https://www. theatlantic.com/international/archive/2012/03/the-white-savior-industrial-complex/254843/ (accessed on 12 August 2018).

Coming to America. 1988. Directed by John Landis. Los Angeles: Paramount. 
Conan the Destroyer. 1984. Directed by Richard Fleischer. Universal City: Universal Pictures.

Cone, James H. 2003. A Black Theology of Liberation. Maryknoll: Orbis.

Cone, James H. 2012. Martin E Malcolm \& America: A Dream or a Nightmare. Maryknoll: Orbis.

Creed. 2015. Directed by Ryan Coogler. Burbank: Warner Brothers.

Daredevil. 2003. Directed by Mark Steven Johnson. Beverly Hills: Twentieth Century Fox.

Davis, Janet M. 2002. The Circus Age: Culture and Society under the American Big Top. Chapel Hill: The University of North Carolina Press.

De Jong, Aleid. 2002. “Feline Dieities". In The Ancient Gods Speak: A Guide to Egyptian Religion. Edited by Donald B. Redford. Oxford: Oxford University Press, pp. 123-24.

Demolition Man. 1993. Directed by Marco Brambilla. Burbank: Warner Brothers.

Desowitz, Bill. 2018. “Black Panther": How Wakanda Got a Written Language as Part of its Afrofuturism. IndieWire. February 22. Available online: https:/ / www.indiewire.com/2018/02/black-panther-wakandawritten-language-ryan-coogler-afrofuturism-1201931252/ (accessed on 10 August 2018).

Enter the Dragon. 1973. Directed by Robert Clouse. Burbank: Warner Brothers.

Evan Almighty. 2007. Directed by Tom Shadyac. Universal City: Universal Pictures.

Finley, Stephen C. 2012. The Meaning of Mother in Louis Farrakhan's "Mother Wheel": Race, Gender, and Sexuality in the Cosmology of the Nation of Islam's UFO. Journal of the American Academy of Religion 80: 434-65. [CrossRef]

Fruitvale Station. 2013. Directed by Ryan Coogler. Los Angeles: Weinstein.

Gay, Roxane. 2017a. Bad Feminist: Essays. New York: Olive.

Gay, Roxane. 2017b. World of Wakanda. New York: Marvel.

Geertz, Clifford. 1973. The Interpretation of Cultures: Selected Essays. New York: Basic.

Harris, Aisha. 2018. "Black Panther's" Dialect Coach on Wakanda's Regional Accents and Prepping Actors. Slate. February 21. Available online: https://slate.com/culture/2018/02/an-interview-with-black-panthersdialect-coach.html (accessed on 10 August 2018).

Heat. 1995. Directed by Michael Mann. Burbank: Warner Brothers.

Hickman, Jonathan. 2014. New Avengers Vol. 3: Other Worlds. New York: Marvel.

Hidden Figures. 2016. Directed by Theodore Melfi. Beverly Hills: Twentieth Century Fox.

Huldin, Reginald. 2017. Black Panther: The Complete Collection. New York: Marvel, vol. 3.

Ikard, David. 2017. Loveable Racists, Magical Negroes, and White Messiahs. Chicago: The University of Chicago Press. Isama, Antoinette. 2018. A Sci-Fi Film about an Otherworldly Village Made of Old Computer Parts in Burundi by Saul Williams is in the Works. OkayAfrica. July 21. Available online: http://www.okayafrica.com/ martyrloserking-neptune-frost-sci-fi-film-saul-williams / (accessed on 5 August 2018).

Jennings, Willie James. 2010. The Christian Imagination: Theology and the Origins of Race. New Haven: Yale University Press.

John, Arit. 2013. Confusing a Country for a Continent: How We Talk About Africa. The Atlantic. August 29. Available online: https://www.theatlantic.com/international/archive/2013/08/confusing-countrycontinent-how-we-talk-about-africa/311621/ (accessed on 6 August 2018).

Johnson, Sylvester A. 2004. The Myth of Ham in Nineteenth-Century American Christianity: Race, Heathens, and the People of God. New York: Palgrave Macmillan.

Jones, LeRoi. 1966. Home: Social Essays. New York: William Morrow.

Knight, Rosie. 2018. Black Panther Writer Don McGregor on Creating Killmonger (Exclusive). Nerdist. February 21. Available online: https:/ / nerdist.com/black-panther-writer-don-mcgregor-killmonger/ (accessed on 6 August 2018).

Kwazulu-Natal. 2013. The Day Mandela Got Arrested. IOL. August 5. Available online: https://www.iol.co.za/ news/south-africa/kwazulu-natal/the-day-mandela-got-arrested-1557672 (accessed on 10 August 2018).

Lawrence, Novotny. 2008. Blaxploitation Films of the 1970s: Blackness and Genre. New York: Routledge.

Lee, Shayne. 2015. Tyler Perry's America: Inside His Films. Lanham: Rowman \& Littlefield.

Liss, David. 2017. Black Panther: The Man without Fear. New York: Marvel.

Live and Let Die. 1973. Directed by Guy Hamilton. Santa Monica: MGM.

Lomax, Tamura A. 2014. Mad Black Bitches and Ladylike Saints: Representations of African American Womanhood in Tyer Perry Films. In Womanist and Black Feminist Responses to Tyler Perry's Productions. Edited by LeRhonda S. Manigault-Bryant, Tamura A. Lomax and Carol B. Duncan. New York: Palgrave Macmillan, pp. 125-46. 
Long, Charles H. 1986. Significations: Signs, Symbols, and Images in the Interpretation of Religion. Philadelphia: Fortress.

Maberry, Jonathan. 2017. Black Panther: Doomwar. New York: Marvel.

Martin, Crystal. 2018. How "Black Panther" Got Its Gorgeous Afrocentric Hair. The New York Times. February 14. Available online: https:/ / www.nytimes.com/2018/02/14/style/black-panther-natural-hair.html (accessed on 23 July 2018).

McCarthy, Todd. 1996. “When We Were Kings": The Incredible Story. Variety. February 11. Available online: https:/ / variety.com/1996/film/reviews/when-we-were-kings-1200445004/ (accessed on 8 August 2018).

McGregor, Don. 2016. Black Panther Epic Collection: Panther's Rage. New York: Marvel.

Means Coleman, Robin R. 2013. Horror Noire: Blacks in American Horror Films from the 1890s to Present. New York: Routledge.

Nina. 2016. Directed by Cynthia Mort. Universal City: Universal Pictures.

Pinn, Anthony J. 1998. Varieties of African American Religious Experience. Minneapolis: Fortress.

Pinn, Anthony J. 2010. Embodiment and the New Shape of Black Theological Thought. New York: New York University Press.

Priest, Christopher J. 2001. “Black Panther" Series Commentary. Adventures in the Funnybook Game: Official Website of Christopher J. Priest. Available online: http:/ / digitalpriest.com/legacy/comics/adventures/ frames/panther_intro.htm (accessed on 6 August 2018).

Priest, Christopher J. 2016. Black Panther. New York: Marvel.

Prothero, Stephen. 2010. God is Not One: The Eight Rival Religions That Run the World-And Why Their Differences Matter. New York: HarperOne.

Quartz, Omar Mohammed. 2015. Will Smith Puts On Hollywood's “African” Accent. The Atlantic. September 11. Available online: https://www.theatlantic.com/politics/archive/2015/09/will-smith-puts-on-hollywoodsafrican-accent/432780/ (accessed on 10 August 2018).

Satchel, Roslyn M. 2017. What Movies Teach About Race: Exceptionalism, Erasure, and Entitlement. Lanham: Lexington. Selma. 2014. Directed by Ava DuVernay. Hollywood: Paramount.

Snead, James. 1994. White Screens, Black Images: Hollywood from the Dark Side. Edited by Colin MacCabe and Cornel West. New York: Routledge.

Spawn. 1997. Directed by Mark A. Z. Dippé. Los Angeles: New Line Cinema.

Star Trek II: The Wrath of Khan. 1982. Directed by Nicholas Meyer. Hollywood: Paramount.

Sun, Rebecca. 2016. India Arie: Why Zoe Saldana as Nina Simone Is "Tone Deaf" Casting (Q\&A). Hollywood Reporter. June 3. Available online: https://www.hollywoodreporter.com/news/india-arie-why-zoesaldana-872960 (accessed on 23 July 2018).

The Green Mile. 1999. Directed by Frank Darabount. Burbank: Warner.

The Help. 2011. Directed by Tate Taylor. Burbank: Buena Vista.

The Legend of Bagger Vance. 2000. Directed by Robert Redford. Los Angeles: Paramount.

The Matrix. 1999. Directed by the Wachowskis. Burbank: Warner.

Trumbore, Dave. 2018. "Black Panther": What Is the Heart-Shaped Herb and What Does It Do? Collider. February 19. Available online: http://collider.com/black-panther-heart-shaped-herb-explained/ (accessed on 1 August 2018).

Wanzo, Rebecca. 2015. It's a Hero? Black Comics and Satirizing Subjection. In The Blacker the Ink: Constructions of Black Identity in Comics \& Sequential Art. Edited by Frances Gateward and John Jennings. New Brunswick: Rutgers University Press, pp. 314-32.

Weiner, Tim. 2007. Legacy of Ashes: The History of the CIA. New York: Doubleday.

When We Were Kings. 1996. Directed by Leon Gast. Universal City: Universal.

Williams, Patrice J. 2018. "Black Panther" Is a Love Letter to Natural Hair. Hello Giggles. February 21. Available online: https:/ / hellogiggles.com/news/black-panther-love-letter-natural-hair/ (accessed on 23 July 2018).

Yaszek, Lisa. 2015. Afrofuturism in American Science Fiction. In The Cambridge Companion to American Science Fiction. Edited by Eric Carl Link and Gerry Canavan. New York: Cambridge University Press, pp. 58-69.

(C) 2018 by the author. Licensee MDPI, Basel, Switzerland. This article is an open access article distributed under the terms and conditions of the Creative Commons Attribution (CC BY) license (http:/ / creativecommons.org/licenses/by/4.0/). 